\title{
Training need analysis for capacitating women SHGs
}

\author{
V. RANDHAWA, R. MITTAL* AND V. KAUR \\ Department of Home Science Extension and Communication Management, Punjab Agricultural \\ University, LUDHIANA(PUNJAB) INDIA \\ (Email : v_randhawa@hotmail.com and veerpal_pau@yahoo.com)
}

\begin{abstract}
Women, the key agents of sustainable development have multiple family and domestic responsibilities which solely rest on their shoulders. But many times due to lack of scientific know how and technical skills, women fail to perform to their optimal capacity and fear to venture into new areas. Hence, an attempt to identify needs of rural women of different SHGs promoted in Hoshiarpur district of Punjab. A sample of 100 women was selected for collection of data to identify the perceived training needs of respondents in different areas of Home Science. The respondents indicated their training needs in terms of most needed, needed and not needed categories. The data was then analyzed by summing up the frequencies of respondents in these categories. Further, training need index and training need scores were also worked out. The results were very encouraging as most of the women appear to be sensitive towards contemporary issues such as energy saving devices, drudgery reducing technologies and income generating technologies. Stitching and embroidery emerged to be the most needed training area. The generated data will have direct utility in organising need based training programmes for potential women entrepreneurs in rural areas. It will also serve as a bench mark to design appropriate training modules for empowerment of rural women in Punjab.
\end{abstract}

KEY WorDs : Training needs, Self-help groups, Training areas, Home science

View Point Article : Randhawa, V., Mittal, R. and Kaur, V. (2015). Training need analysis for capacitating women SHGs. Internat. J. Home Sci. Extn. \& Comm. Manage., 2 (2): 109-115.

Article History : Received : 01.06.2015; Revised : 28.06.2015; Accepted : 30.06.2015

\footnotetext{
* Author for correspondence

(Email : rituhsee@pau.edu )
} 